\title{
Design Development of Infographics Content for Covid- 19 Prevention Socialization
}

\author{
Vinda Maya Setianingrum ${ }^{1, *}$ Anam Miftakhul Huda ${ }^{1}$ Gilang Gusti Aji ${ }^{1}$ Puspita Sari \\ Sukardani ${ }^{1}$ Muh Ariffudin Islam ${ }^{2}$ \\ ${ }^{1}$ Communication Department, Universitas Negeri Surabaya, Surabaya, Indonesia \\ ${ }^{2}$ Visual Communication Design Departement, Universitas Negeri Surabaya, Surabaya, Indonesia \\ *Corresponding author. Email: vindasetianingrum@unesa.ac.id
}

\begin{abstract}
The aim of this study is to find out how the series of Unesa Crisis Center (UCC) activities in presenting Covid19 visual objects to the public, through infographics in Covid-19 alert socialization. Next, examine the public response to the infographic of Covid-19 alert socialization applied by Unesa Crisis Center (UCC) to the general public, students specifically as Covid-19 mitigation education media. This research method was developed in the form of infographics for Covid-19's socialization media carried out by the Unesa Crisis Center (UCC) as an institution of Universitas Negeri Surabaya which had a concern for Covid-19 interception in Indonesia. This study uses qualitative approaches, it based on the formulation of the problem chosen in the study, so that researchers explore the focus of the problem. Next, the researcher collected various data and information through interviews and observations, along with literature studies and documentation of the data sources needed. The results of the study show that the infographics applied by Unesa Crisis Center (UCC) for Covid 19 socialization have not been maximized so the public interest is lacking, in infographic development emphasizing the systematic aspects of the lockdown situation, work from home (WFH), and sistuational saturation and anxiety in the community during activities to reduce the breaking of the Covid-19 chain.
\end{abstract}

Keywords: Design and contents, Infographics, Covid 19, Unesa Crisis Center

\section{INTRODUCTION}

The development of knowledge in line with technological advances also affects the development of human thought for adaptation in life, as well as problems in information that are currently being discussed around the world, it's about the spread of Corona Virus or Covid-19. Information technology becomes a mediator for the rapid transformation of knowledge about the existence of this virus.

Coronavirus or known as Novel Corona Virus or $\mathrm{nCoV}$, according to the World Health Organization (WHO) stands for "coronavirus disease that was discovered in 2019" which is also a large family of Corona Virus $(\mathrm{CoV})$, and then officially referred to globally as Covid-
19. The virus becomes the main topic and attention of the world, as well as Indonesia. This virus is unique because in addition to being able to live in inanimate media, it can also replicate in living cells, in addition to being infectious and also deadly. Initially this virus spread out in the province of Wuhan in early 2020 and the Chinese government announced as a deadly virus. As a new and deadly virus, extra efforts are needed: the most affordable is by implementing an incubation and quarantine period of 14 to 24 days [1].

Being calm in the face of an epidemic and maintaining health is one of the conditions recommended by experts. The impact of panic is not only on oneself, but also to the other people. Obeying the protocols that have been set by the government through regulations is one way to create this calm [2]. 
Handling the epidemic must also involve cross-sectoral coordination and cross-program making is also a priority. This handling effort includes a series of activities starting before the epidemic and disaster, which is carried out through prevention, mitigation and preparedness activities. Furthermore, the emergency response in the aftermath takes the form of recovery, rehabilitation and reconstruction activities. Crisis response due to epidemics and disasters must have the same perception of problems and complete solutions. The Covid-19 epidemic has also become a momentum to increase the concept of good clinical governance because the socialization of clinical guidelines in the form of distribution of printed guides or presentations that are too dictating in nature often proves ineffective. Interventions need to be selected using a variety of approaches such as clinical audits, developing reminder systems and also leveraging clinical leadership to improve adherence to guidelines [3].

In some countries, there have been preventive measures such as imposing lockdowns for their territories; it is a way to break the chain of spreading Covid-19. Although the impact of the lockdown will affect the fabric of society, such as hampered economic aspects, the government believes this step is effective in its function to overcome the increasingly widespread spread of Covid-19 [2].

The role of the mass media is very important in providing good and correct information. The media as one of the pillars of information distribution has a big responsibility to convey information proportionally, one of them is by presenting it with an infographic model of information on the development of Covid-19 which is always up to date.

Infographics are a general concept of presenting information which in its application is based on creativity, beauty (attractiveness), accuracy of the content with illustrations, and the effectiveness of the time to interpret information [4].

The use of infographics has been widely used in presenting information, it is because infographics can simplify complex information into information that can be easily understood, infographics are also able to attract the attention of various groups of people, the application of information in the form of infographics also has advantages because it can be easily understood, be remembered. Infographics are data visualizations to provide information to readers that are represented through graphic objects so they are attractive and easy to understand [5].

The mistake of understanding infographics is because infographics often appear to be graphs (charts) even though basically a simple photography simulator is able to help understand information more clearly: infographics as a part of visual literacy require that the information conveyed to readers is responded to appropriately according to the purpose and context of the information. Visual literacy is also a continuous process because it will increase the knowledge possessed by the community and infographers, especially about how to translate or create visual messages appropriately and relevant to existing textual information [5].

The public today has also been given a variety of simple simulations regarding visual information such as symbols or logos that are distributed through various media. With the consideration that the community has received a simple visual stimulus in the surrounding environment, currently many institutions often use the services of infographers to describe of the important information and complex in nature to suit the needs of their institutions. Even using infographers is to improve the image of a company by using infographics as a medium to increase promotion. At the same time, the need for infographic services in making infographics is also very strategic. Infographers are currently one of the professions that are being needed both in terms of delivering news or in delivering information of a commercial nature [6].

The media used as a means of this research and development is social media. Social media can be likened to a collection of various countries or groups of people who are connected, interact, and bound by certain rules [4].

Social media has the ability to reach the user community at the same time, both individually and in the community. With this very broad reach, social media is an effective means of conveying messages related to awareness behavior in maintaining health and safety when entering a new life era (new normal) during the Covid-19 pandemic. Regarding media, this research uses microblog-based social media, namely Instagram as a platform for media development.

\section{RESEARCH METHODS}

This research was developed in the form of an infographic for the socialization media for Covid-19 which is carried out by UCC as a university institution that has concerns about the prevention of Covid-19 in Indonesia. This research uses qualitative and quantitative approaches; it is based on the formulation of the problems selected in the study, so the researcher explores the focus of the problem. Furthermore, the researcher collected various data and information through interviews and observations, along with literature studies and documentation of the required data sources. 
The method used is research and development, is a research method used to research in an effort to develop existing products (innovation) and to create new products (creations) that are tested [7].

The development research procedure is guided by the development research design which consists of the development design of teaching materials that is often used is the ADDIE Model through 5 stages; Analysis, Design, Development, Implementation and Evaluation.

\section{RESULTS AND DISCUSSION}

In designing an infographic poster as the main output product, there are several steps taken to achieve the final result. The design stage process through a series of studies is in the form of theoretical studies and visual studies. This stage is carried out to get the maximum output product. In the infographic poster design process, go through the following stages

\subsection{Establishment of UCC Infographic Scripwriting and Storytelling}

The scripwriting process is carried out as an initial step in finding the main idea which will be translated into a visual poster. In the method of conveying messages from an infographic, it is not only through visual appearance, but the most important thing is the information displayed in a poster. In stages, the main idea of the concept is adjusted when compared to the first idea when in the research proposal process. It is because the conditions caused by Covid-19 have also experienced significant shifts and changes. Government policies and the socioeconomic conditions of health have also adjusted. Therefore the main concepts and themes that will be displayed in the main output of this study are the socialization of the new normal era and how it is applied in society, so that the spread of Covid-19 does not become more widespread.

In this stage, the process carried out is to create a main theme that will be translated into sub-themes, and then it will be poured into the elaboration of information about each theme raised. In this case, the sub-theme is to discuss the steps and procedures for a new normal life in the Covid-19 era. Defined a main tagline that will be communicate 10 sub themes, which are made into 10 sub taglines. The sub tagline is then described about what information needs are needed to support the sub-theme

The results of the process of determining the tagline, sub tagline, and supporting information that will be used in the design process of the campaign infographic poster are as follows: Office, school, shopping, worshiping, exercising, recreation, traveling, recreation.
In making infographics, the use of storytelling as a way and style to convey information is a major concern. Because the strength of an infographic is not only the strength of the visual layout, but also the storytelling which is displayed. Storytelling in an infographic is generally adjusted to the target audience, and in this case, because the design of this infographic is part of the UCC concept in dealing with Covid-19 in the Surabaya State University academic community and surrounding communities, the storytelling style used is by way of which is more straightforward, goes straight to the point, by using easy-to-understand word choices across generations.

\subsection{Moodboard Development in UCC Era New Normal Infographic}

The moodboard process is generally carried out for the purposes of visual design literacy, both in terms of choosing colors, fonts, design styles, and visual elements that can be used as references so as to simplify the design concept process. Moodboard is basically a visual guide that will facilitate the process of further visual implementation.

The moodboard process is carried out by collecting pieces of literacy and visual references, which are related to the overall theme and sub-theme. It is hoped that the use of a visual moodboard will provide visual consistency in each of the resulting infographic poster outputs.

\subsection{Alternative Visual Concept Development on UCC Infographics}

Visual concept is an initial idea that will be used to form visual characters in a design. After going through the stages of drafting script writing and moodboard, the visual concept is compiled in the following stages.

a) Look for visual reference infographics

Visual references are gathered to help graphic designers visualize media. Visual references aim to assist and guide graphic designers when drafting visual concepts.

b) Arranging a grid layout

Grid layout is useful for balancing the position of graphic elements such as text, images and diagrams to be visualized in the media. Some examples of applying the Grid, can be seen in the following image. 


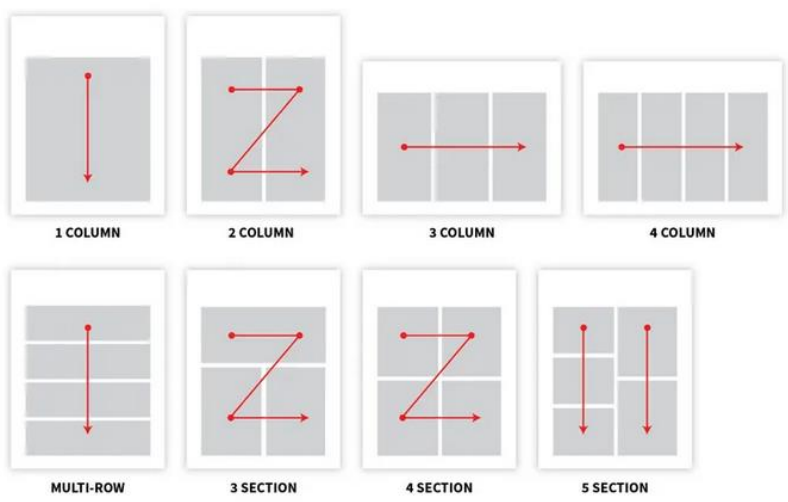

Figure 1 Grid layout on the application of infographics

In addition to adjust the composition and layout of the design, the grid functions to determine the reading flow, so the information on the media can be translated properly by the audience.

\subsection{The Implementation of UCC Era New Normal's Infographic Visual Exploration}

The visual exploration process aims to get the right visualization and in accordance with the target audience, but still refers to the principles of preparing the correct infographics. In this development research, several alternatives were carried out to explore the design style process which also refers to design trends in the last two years, including a minimalist design using characters and gestures to convey messages. In addition, a simple design style is considered more capable of communicating messages more explicitly. In this exploration stage, several design styles are deemed appropriate to the target audience which is developed to become visual alternatives.

In the alternative visual stage, several visual choices are made which will be developed and implemented into the final design. Some examples of alternative visuals produced are as follows.
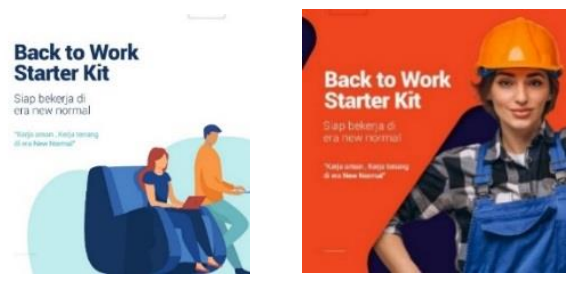

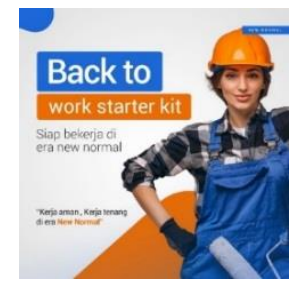

Figure 2 Visual Alternatif 1, 2, and 3

After passing through these stages, poll results were obtained from the audience test about the desired design style and were considered more appropriate and able to communicate messages well. From the results of the audience test, design style number 1 was chosen, because it is stronger in terms of visual principles and more neutral in the use of characters because it does not refer to certain human characters / figures, so the message conveyed visually will be more universal.

The visual implementation is based on 10 main concepts which are appointed as the main points of the campaign for the way of life in the new normal era. These 10 concepts were obtained by referring to the standardization pattern applied by WHO, the Indonesian Doctors Association, and the Government.

The use of the communication concept used in the content is to focus on important messages carried out in the new way of life (new normal) during the Covid 19 period. The main audience focus of this socialization campaign is not only limited to followers of the UCC account on Instagram, but more widely, it is hoped that it can become a campaign that can be spread virally so it becomes educational material in the wider community.

The final design uses illustration techniques with character models that can be generally understood in terms of visual gestures and gender and age selection in each design, so that the message will be more easily understood and liked by the audience.

The overall implementation of the resulting visual content is as follows.

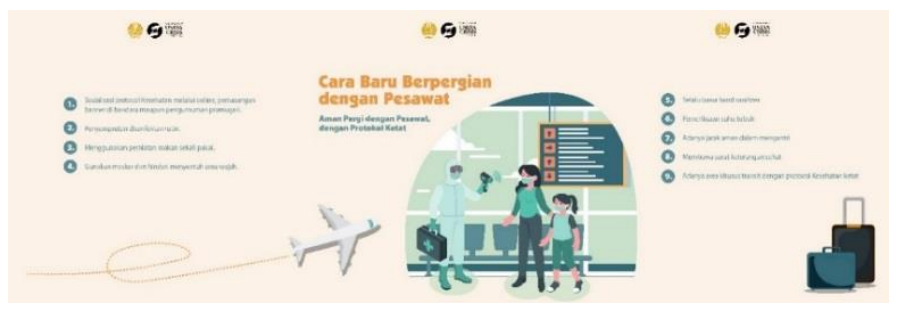



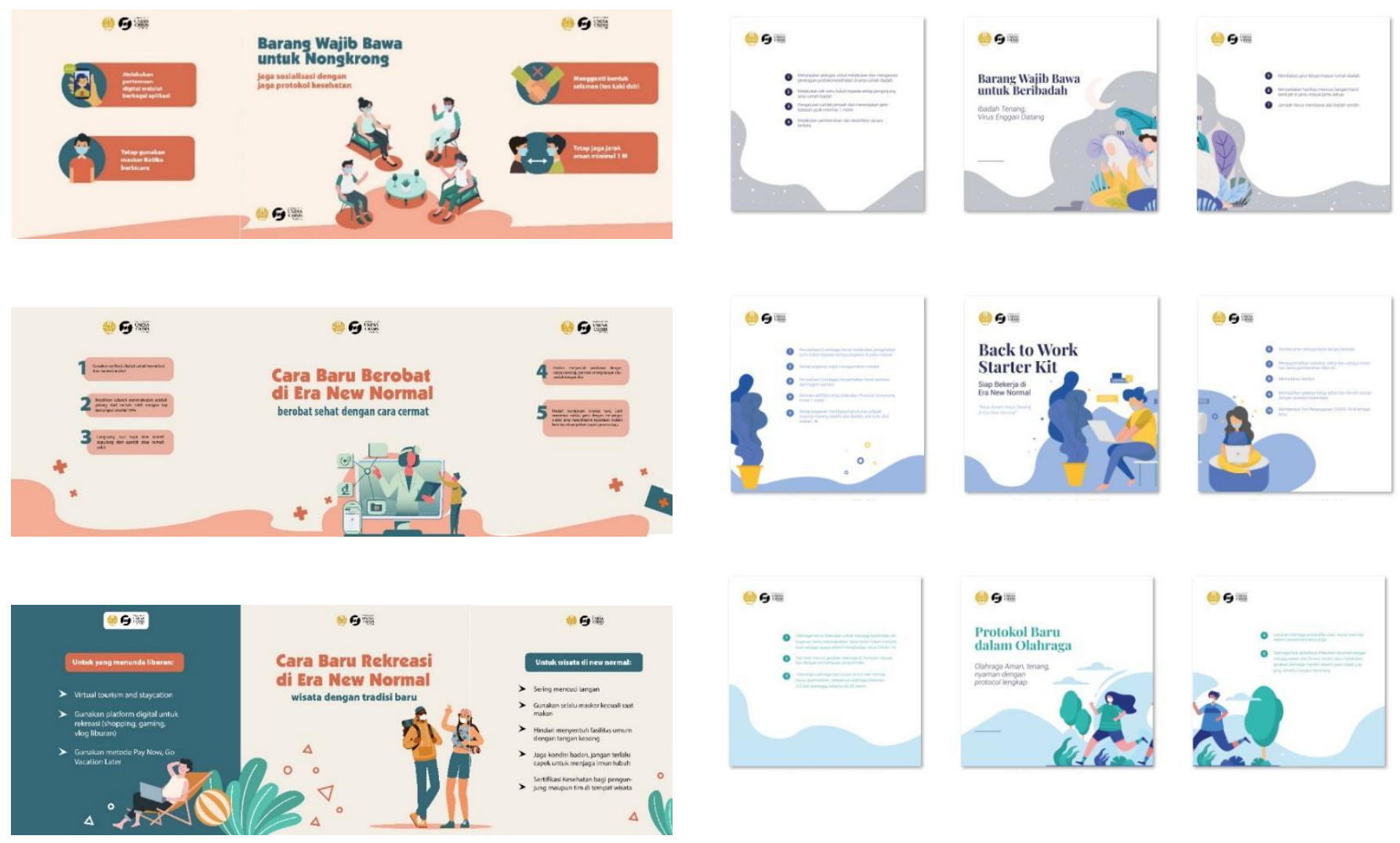

The selection of graphics, characters, visual fields, and layouts emphasizes a minimalist, clean design style, using pastel colors, especially for the use of background colors, so the main information content can be seen more clearly and in focus.

The selection of grids for Instagram content is made by connecting 3 grids to 1 so when viewed in thumbnails, visual information will be presented in full. This is intended so the audience does not only see one content, but there is repetition and continuation so it will have a stronger engagement effect.

\subsection{Public Response to the UCC New Normal Infographic Results}

Infographic is a way of conveying messages that are shorter, easy to understand but still interesting. This type of media has been widely used in various media. In the socialization of information about Covid-19, several social media on the Instagram platform, such as @WHO, @jatimsiagacovid, and @ satuantugascovid19 also brought up types of infographics to make it easier for followers to understand. "This type of infographic is easily found on various social media" interviewed with Kuridha, August 13, 2020. 
It indicates that the type of infographic has become a new style of presenting information. The five respondents who have followed the @ucc_unesa account admit that they already know this type of infographic. "I see the infographics which displayed are good, funny, the colors are not monotonous and more millennial" interviewed with Hervina Vidya Safira, 13 August 2020.

Although presenting the data briefly, in fact this type of data processing such as infographics is preferred. "I prefer information that contains images, so it is eye cetching. If it's only text, it feels more boring and makes me lazy to read " interviewed with Lintang Novitasari on August 13, 2020.

Followers have specific criteria for consuming infographics. The combination of a good design and a short but clear explanation is a must-have criterion. "Color games as well as word games, selection of diction are points that must be featured in uploading infographics" interviewed with Hervina Vidya Safira on August 13, 2020. This statement is supported by the importance of presenting short, concise and clear information. "Good infographics have clear sentences and are not wordy" interview with Zhafran Basyrar on August 13, 2020

From the uploading of the @ucc_unesa infographic, all respondents stated that they understood the message conveyed. "Infographics make me understand data more than just looking at the text" interview with Kuridha Dwi. However, there are some additional points that must be improved in presenting infographics, such as choosing an appropriate font. "The writing on the infographic at @ucc_unesa seems too small. It takes more effort to see because scrolling activities on social media usually take place quickly " interviewed with Zhafran Basyrar, 13 August 2020.

\section{CONCLUSION}

The speed and accuracy of information is very suitable to be applied in this era of technological acceleration because people tend to be accustomed to moving quickly, including in understanding information.

As a suggestion, although the infographic contains brief information, it must be sure to be precise. It can be done by including the source in the corner of the content.

Infographic can be a solution for presenting data other than text that can be applied to social media. However, the selection of images, fonts and words must also be precise and interesting, so the followers or viewers are interested in reading more in detail.

\section{ACKNOWLEDGMENT}

We would like to express our gratitude to Universitas Negeri Surabaya a place the researchers served, and all those who helped carry out this research. Thank you, LPPM, Universitas Negeri Surabaya for facilitating the 2020 PNBP funding so this research runs well.

\section{REFERENCES}

[1] H. Djasri, "Corona Virus dan Manajemen Mutu Pelayanan Klinis di Rumah Sakit," J. Hosp. Accredit., vol. 2, no. 1, pp. 1-2, 2020.

[2] N. R. Yunus and A. Rezki, "Kebijakan Pemberlakuan Lock Down Sebagai Antisipasi Penyebaran Corona Virus Covid-19," SALAM J. Sos. dan Budaya Syar-i, vol. 7, no. 3, pp. 227-238, 2020.

[3] R. Ristrini, R. Rukmini, and O. Oktarina, "Analisis Implementasi Kebijakan Kesiapsiagaan Penanggulangan Bencana Bidang Kesehatan Di Provinsi Sumatera Barat," Bul. Penelit. Sist. Kesehat., vol. 15, no. 1 Jan, pp. 91-102, 2013.

[4] M. Mulawarman and A. D. Nurfitri, "Perilaku Pengguna Media Sosial beserta Implikasinya Ditinjau dari Perspektif Psikologi Sosial Terapan," Bul. Psikol., vol. 25, no. 1, pp. 36-44, 2017.

[5] F. Saptodewo, "Desain Infografis Sebagai Penyajian Data Menarik," J. Desain, vol. 01, no. 03, pp. 193-198, 2014.

[6] S. Mulianazar, "Komunikasi Persuasif Dinas Kesehatan Kota Pekanbaaru dalam Upaya Pencegahan Demam Berdarah (DBD)," Jom, vol. 4, no. 41, pp. 1-15, 2017.

[7] M. B. Bungin, Metode Penelitian Kuantitatif. Jakarta: Kencana, 2008. 